\title{
Molecular Identification of Oidium neolycopersici as the Causal Agent of the Recent Tomato Powdery Mildew Epidemics in North America
}

Levente Kiss, Plant Protection Institute of the Hungarian Academy of Sciences, H-1525 Budapest, P.O. Box 102, Hungary; Susumu Takamatsu, Laboratory of Plant Pathology, Faculty of Bioresources, Mie University, Tsu 5148507, Japan; and James H. Cunnington, Department of Primary Industries - Knoxfield, Private Bag 15, Ferntree Gully Delivery Centre, Victoria, 3156, Australia

\begin{abstract}
Kiss, L., Takamatsu, S., and Cunnington, J. H. 2005. Molecular identification of Oidium neolycopersici as the causal agent of the recent tomato powdery mildew epidemics in North America. Plant Dis. 89:491-496.

A previous morphological study of Oidium anamorphs responsible for the recent tomato (Lycopersicon esculentum) powdery mildew outbreaks worldwide suggested that, despite controversial data in the literature, the North American epidemics were caused solely by a newly erected species, $O$. neolycopersici. We report here the first molecular evidence that the North American anamorphs do belong to $O$. neolycopersici. The internal transcribed spacer sequences of the North American anamorphs of this study were identical with those of three Japanese and four European specimens of $O$. neolycopersici. A morphological study confirmed that all the North American Oidium anamorphs included in this study produced conidia singly, similar to $O$. neolycopersici. These fungi were readily distinguished from $O$. lycopersici, which produces conidia in chains and is known to infect tomato only in Australia. The phylogenetic analysis showed that $O$. neolycopersici is a distinct powdery mildew species, and it is neither identical nor closely related to any known polyphagous species of the Erysiphaceae. Apparently, it was introduced into the United States and Canada only in the 1990s, but its origin is still unknown.
\end{abstract}

Additional keywords: Erysiphe sp.

In the late 1970s, an apparently new powdery mildew disease appeared on tomato (Lycopersicon esculentum) in Japan (2) and Australia (52,70). Later, outbreaks of a similar disease were reported from many parts of Europe $(9,12,14,19,20,34$, 38,46-48,64,67) and North America (5$7,31,41,49,57,68)$. In all these reports, the causal agent of the novel epidemics causing economic damage to tomato has been described as an Oidium anamorph and has always been clearly distinguished from Oidiopsis, the anamorph stage of Leveillula taurica, long known to affect tomato in warmer regions of the world (10). However, the reported data on the conidiogenesis of the novel pathogens were contradictory. Some authors described an Oidium anamorph on tomato that produces conidia in chains $(2,5,7,14,31,34,46,49,52,68,70)$, while others reported a pathogen producing conidia singly $(6,9,20,38,41,47,48$, $57,64,67)$. As the nature of the conidiogenesis is a stable pattern within powdery mildew species $(10,11,13,54)$, the contra-

Corresponding author: L. Kiss

E-mail: lkiss@nki.hu

Accepted for publication 29 December 2004.

DOI: 10.1094/PD-89-0491

(C) 2005 The American Phytopathological Society dictions in the reported data suggested that the tomato powdery mildew epidemics might have been caused by more than one species in different parts of the world or even in the same geographical region. For example, Oidium anamorphs with both catenate and non-catenate conidia were reported on tomato in the United States $(5,31,41,49,57,68)$, Canada $(6,7)$, Switzerland $(9,14)$, and Japan $(2,32,43)$.

The conflicting data regarding the conidiogenesis of the tomato powdery mildew pathogens were further complicated by a variation in the pathogenicity of these Oidium anamorphs. For example, considerable differences were found in the host range of Oidium anamorphs causing epidemics on tomato in England (67), Connecticut (37), the Netherlands (25), and Japan (32). In addition, Lebeda and Mieslerova (39) suggested the existence of three pathotypes based on the differences in the pathogenicity of four European Oidium isolates on many accessions of wild Lycopersicon spp. Overall, these results suggest a considerable genetic diversity within these poorly delimited pathogens or even the existence of more than one species causing a similar disease on tomato.

Only a few tomato genotypes, such as the breeding line Hirol 3-21 (37) and cv. Grace (33), were reported to be resistant to the novel powdery mildew infections, al- though Kashimoto et al. (33) have recently showed that cv. Grace is susceptible to a Japanese isolate of the fungus. Most tomato cultivars grown worldwide are susceptible to the disease $(25,29,37,40,43)$. Thus, there is a need to breed cultivars resistant to powdery mildew infections caused by Oidium anamorphs $(25,29,37,40)$.

The uncertainties in the identity of the tomato powdery mildew pathogens pose a practical problem for tomato breeders. If two or more species were responsible for the recent outbreaks, this would complicate the breeding strategy, as in the case of certain melon lines that were infected by both Erysiphe and Podosphaera (syn. Sphaerotheca) species (16). Recent studies showed that some Arabidopsis thaliana accessions were susceptible to two powdery mildew species, Golovinomyces cichoracearum (syn. E. cichoracearum) and E. cruciferarum, whereas other accessions were resistant to one or both of them $(3,65)$. Differential resistance to more than one powdery mildew species complicates the task of breeding. Thus, there was not only a taxonomical, but also a practical need to determine how many species are responsible for the recent tomato powdery mildew pandemics.

In order to identify the causal agent(s) of the tomato powdery mildew epidemics, Kiss et al. (35) carried out an extensive study of more than 50 tomato powdery mildew specimens, including fungi maintained on living plants and herbarium materials, obtained from all continents where tomatoes are grown. Based on the combined use of classical morphological, scanning electron microscope (SEM), and molecular analyses, these authors concluded that a single Oidium anamorph producing single, non-catenate conidia infected tomato in Europe, North and South America, Asia, and Africa. This was described as a new species, Oidium neolycopersici Kiss. Surprisingly, a morphologically distinct Oidium anamorph, producing conidia in chains, was found on all the tomato materials obtained from Australia. This was neotypified as $O$. lycopersici Cooke \& Massee emend. In the molecular part of the study, Kiss et al. (35) determined the internal transcribed spacer (ITS) sequences of the ribosomal DNA (rDNA) in two specimens of $O$. neolycopersici, collected in France and the Netherlands, 
respectively, and found that they were almost identical. The ITS sequence was determined in the Australian chain-forming $O$. lycopersici as well, and a phylogenetic analysis showed that it was not closely related to $O$. neolycopersici (35). Later, Kashimoto et al. (32) showed that the rDNA ITS sequences of three Japanese non-catenate powdery mildew anamorphs were almost identical with those of the two European $O$. neolycopersici specimens sequenced. The other tomato powdery mildew pathogens collected in Europe, Asia, Africa, and the Americas were identified as $O$. neolycopersici based on their morphological characteristics only $(29,35,44,67)$.

In some cases, powdery mildew infections of the same plant species could be caused by more than one species whose anamorphs are sometimes morphologically indistinguishable. If symptoms of the infections and morphology of the pathogens were similar, and the teleomorph stage was not seen, only a detailed microscopic and molecular study could reveal the exact identity of the causal agent of the disease. For example, soybean powdery mildew epidemics in Asia were caused by noncatenate Oidium anamorphs of two different species, Erysiphe glycines and E. diffusa (syn. Microsphaera diffusa), which sometimes occurred simultaneously on the same plant (62). However, molecular tools could distinguish them in the absence of the teleomorphs that were produced only sporadically by E. glycines and not at all by E. diffusa (62). Similarly, an extensive study showed that powdery mildew epidemics on Rhododendron in Europe were caused by at least two species, E. azaleae and $E$. digitata (27). It was not until the 1990s that the first ascomata of these two species were observed on Rhododendron in Europe, making their identification possible. Until then, only non-catenate Oidium anamorphs were found on Rhododendron, which could not be distinguished based on their morphological and SEM patterns (27). Other examples of the infection of the same plant species by morphologically similar powdery mildew anamorphs representing different species or even different genera were presented by Cunnington et al. (15) based on the molecular identification of the pathogens involved.

The sexual stage of $O$. neolycopersici is unknown. Attempts to produce ascomata in vitro have failed (35). In light of the case studies presented above, the morphological evidence presented by Kiss et al. (35) might not be sufficient to support claims that all the recent tomato powdery mildew epidemics outside Australia were caused solely by this species. Clearly, more precise methods are needed to reliably identify the causal agent(s) of this disease worldwide. This is particularly important for the North American epidemics, as none of the tomato powdery mildew pathogens collected in the United States and Canada were identified using DNA sequence data. So, it might be possible that they represent more than one species with morphologically indistinguishable anamorphs.

Phylogenetic studies based on the rDNA ITS region of powdery mildews have resulted in a large data set for molecular identification of various taxa of the Erysiphaceae $(11,42,45,54,59-62)$. The analyses of ITS sequences of powdery mildew specimens belonging to the same species showed that they are nearly or completely identical within a given species $(23,42,62)$. This is the case in $O$. neolycopersici, as Kashimoto et al. (32) recently showed that the ITS sequence from six isolates collected in different European countries and Japan is 99 to $100 \%$ similar. Thus, we proposed in this work to determine and to analyze the ITS sequences of North American and European tomato powdery mildew pathogens in order to determine whether the recent tomato powdery mildew epidemics in North America were caused solely by $O$. neolycopersici. For comparison, a few specimens of $O$. $l y$ copersici, which produces conidia in chains and whose known distribution is restricted to the southern parts of Australia, were also included in this study.

\section{MATERIALS AND METHODS}

Fungal materials and microscopy. A total of 22 tomato samples infected with powdery mildew were obtained from the United States, Canada, Japan, and Europe (Table 1) and were examined as fresh materials or as herbarium specimens using

Table 1. List of the Oidium neolycopersici specimens examined in this study using light microscopy and analysis of the rDNA internal transcribed spacer (ITS) sequences ${ }^{\mathrm{a}}$

\begin{tabular}{|c|c|c|c|c|c|}
\hline Designation & $\begin{array}{l}\text { Herbarium } \\
\text { accession no. } \\
\text { (if available) }^{\text {b }}\end{array}$ & Place and year of collection & Collected by & $\begin{array}{l}\text { GenBank accession } \\
\text { no. of ITS sequence } \\
\text { (if determined) }\end{array}$ & $\begin{array}{l}\text { Source of the ITS } \\
\text { sequence data }\end{array}$ \\
\hline \multicolumn{6}{|c|}{ North America } \\
\hline MD1 & BPI 746232 & Beltsville, MD, USA, 1999 & L. Kiss & AB163915 & This paper \\
\hline MD2 & - & Germantown, MD, USA, 1999 & L. Kiss & - & \\
\hline CAN & BPI 746230 & Harrow, ON, Canada, 1999 & R. Cerkauskas & AB163914 & This paper \\
\hline $\mathrm{CA}$ & $\begin{array}{l}\text { MUMH775 } \\
\text { (BPI 746433) }\end{array}$ & Oxnard, CA, USA, 1999 & R. M. Davis & AB034722 & This paper \\
\hline CT1 & BPI 746456 & New Haven, CT, USA, 1998 & V. L. Smith & - & \\
\hline $\mathrm{CT} 2$ & BPI 746457 & New Haven, CT, USA, 1998 & V. L. Smith & - & \\
\hline LI & BPI 746228 & Riverhead, NY, USA, 1999 & M. T. McGrath & - & \\
\hline GEN & BPI 746231 & Geneva, NY, USA, 1999 & L. Kiss & - & \\
\hline ITH & BPI 746229 & Ithaca, NY, USA, 1999 & D. Kalb & - & \\
\hline MOR & - & Morristown, NY, USA, 2003 & L. Kiss & - & \\
\hline CAN2 & - & Ste-Anne-de-Bellevue, QC, Canada, 2003 & L. Kiss & - & \\
\hline \multicolumn{6}{|l|}{ Europe } \\
\hline Et1 & BPI 747013 & Aigue Mortes, France, 1989 & P. C. Nicot & AF229019 & Kiss et al. (35) \\
\hline NETH & VPRI 20724 & Wageningen, Netherlands, 1994 & H. van Kesteren & AF229015 & Kiss et al. (35) \\
\hline PV & BPI 746227 & Wageningen, Netherlands, 1999 & C.-C. Huang & - & \\
\hline UK1 & - $\quad$ n & York, UK, 1999 & R. T. A. Cook & - & \\
\hline UK2 & VPRI 20381 & Wellesbourne, UK, 1994 & J. M. Whipps & AB163916 & This paper \\
\hline BULG & VPRI 20360 & Bulgaria, 1994 & G. Neshev & AB163913 & This paper \\
\hline BP-P5 & BPI 746455 & Budapest, Hungary, 1998 & L. Kiss & - & \\
\hline SW & BPI 746225 & Nyon, Switzerland, 1995 & A. Bolay & - & \\
\hline \multicolumn{6}{|l|}{ Japan } \\
\hline JAP1 & MUMH66 & Toyama, Japan, 1995 & Y. Sato & AB032483 & Kashimoto et al. (32) \\
\hline DNA231 & - & Toyama, Japan, 1996 & Y. Sato & AB032484 & Kashimoto et al. (32) \\
\hline КTP01 & - & Nara, Japan & & AB094991 & Kashimoto et al. (32) \\
\hline
\end{tabular}

${ }^{a}$ Some specimens were also included in previous studies carried out by Kiss et al. (35) and Kashimoto et al. (32).

${ }^{\text {b }}$ BPI = U.S. National Fungus Collection, Beltsville, MD; MUMH = Mie University Mycological Herbarium, Japan; VPRI = Plant Disease Herbarium, Institute for Horticultural Development, Victoria, Australia. 
light microscopy as described in Kiss et al. (35). Herbarium materials were rehydrated before study using the method developed by Shin and La (56). Three North American and two European tomato powdery mildew specimens producing conidia singly were selected for molecular analyses. For comparative light microscopy studies, three specimens of $O$. lycopersici collected in Victoria, Australia, in 1980 (DAR 35762, DAR 35763, and DAR 35764) were also included in this work.

DNA extraction and amplification of rDNA ITS sequences. Whole-cell DNA was isolated from powdery mildew mycelia using the Chelex method $(24,66)$. The nuclear rDNA region spanning the ITS1, ITS2, and 5.8S rRNA gene was amplified by polymerase chain reaction (PCR). Primers ITS5 (69) and P3 (36) were used for the first amplification, which was performed in a total reaction volume of $50 \mu \mathrm{l}$, including the following reagents: PCR buffer (10 mM Tris-HCl, pH 8.3, $50 \mathrm{mM}$ $\mathrm{KCl}, 1.5 \mathrm{mM} \mathrm{MgCl} 2,0.01 \%$ gelatine); 200 $\mu \mathrm{M}$ of each deoxyribonucleotide triphosphate; $0.4 \mu \mathrm{M}$ of each primer with $10 \mu \mathrm{l}$ of the template DNA solution; and one unit of Taq DNA polymerase (TaKaRa, Tokyo, Japan). The following thermal cycling conditions were performed in a thermal cycler PC-700 (ASTEC, Fukuoka, Japan): an initial denaturing step at $95^{\circ} \mathrm{C}$ for 2 min; thermocycling for 30 cycles, where each cycle consisted of $30 \mathrm{~s}$ at $95^{\circ} \mathrm{C}$ followed by $30 \mathrm{~s}$ at $52^{\circ} \mathrm{C}$ for annealing, and $30 \mathrm{~s}$ at $72^{\circ} \mathrm{C}$ for extension; and a final extension cycle of $7 \mathrm{~min}$ at $72^{\circ} \mathrm{C}$. One microliter of the first amplification mixture was used for a second amplification using the nested primer set ITS1 (69) and P3. Components of the reaction mixture and the thermal cycle conditions for the second amplification were the same as for the first one. Each PCR product was subjected to electrophoresis in $1.5 \%$ agarose gel in TAE buffer. The DNA product of each amplification was then excised from the ethidium bromide-stained gel and purified using the JETSORB kit (GENOMED, Oeynhausen, Germany) following the manufacturer's protocol.

DNA sequencing. Nucleotide sequences of the PCR products were obtained for both strands using direct sequencing in an Applied Biosystems 373A DNA sequencer. The sequence reactions were conducted using the PRISM Dye Terminator Cycle Sequencing FS Ready Reaction kit (Applied Biosystems, Foster City, CA, USA) following the manufacturer's protocol. Four primers, ITS1 (69), P3, T3, and T4 (24), were used for the sequencing in both directions.

Phylogenetic analysis. ITS sequences of five $O$. neolycopersici specimens and of 49 other powdery mildew fungi with noncatenate anamorphs were obtained from DNA databases and were aligned with the newly obtained sequences using the
ClustalX package (63). The ITS sequence of the chain-forming $O$. lycopersici (GenBank accession no. AF229021) was not included in the analysis because it is highly divergent from the sequences of the non-catenate Oidium anamorphs (35). The alignment was then refined visually using a word processing program with color-coded nucleotides, and ambiguously aligned sites were removed from the data set for the following analyses. The final alignment was deposited in TreeBASE under the accession number S1201/M2073. Phylogenetic trees were obtained from the data using maximum-likelihood (ML), neighbor-joining (NJ), and maximum parsimony (MP) methods. For ML and NJ analyses, the most appropriate evolutionary model was determined for a given data set using PAUP* 4.0b8 (58) and Modeltest 3.06 (51). A starting tree was obtained with $\mathrm{NJ}$ method. With this tree, likelihood scores were calculated for 56 alternative models of evolution by PAUP*. The output file was then imported to Modeltest to compare the models by using Akaike's (4) information criterion. Once a model of evolution was chosen, it was used to construct phylogenetic trees with ML method using Treefinder version March 2003 (G. Jobb, Treefinder. Published online.) and NJ method using PAUP*. For the parsimony analysis, we used the maximum-parsimony (MP) method with a heuristic search using PAUP*. This search was repeated 100 times with different random starting points, using the stepwise addition option to increase the likelihood of finding the most parsimonious tree. Transversions and transitions were treated as equal weight. All sites were treated as unordered, with gaps treated as missing data. The branchswapping algorithm was TBR, the MULPARS option was in effect, and zerolength branches were collapsed. The strength of the internal branches from the resulting trees was tested by the bootstrap analysis (18) using 1,000 replications in

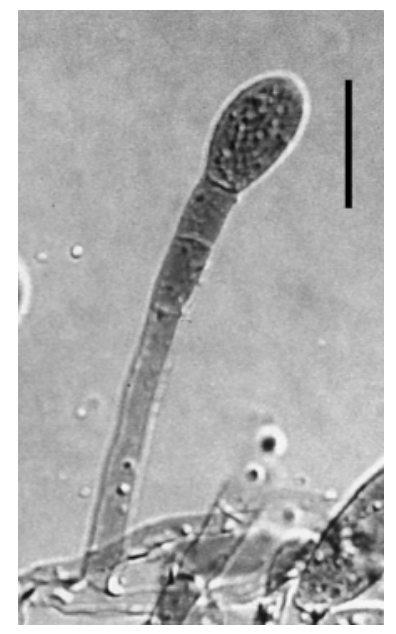

Fig. 1. A conidiophore of Oidium neolycopersici isolate MD1 (BPI 746232) collected in Beltsville, $\mathrm{MD}$, in 1999. $\mathrm{Bar}=30 \mu \mathrm{m}$.
MP and NJ analyses and 100 replications in ML analysis.

\section{RESULTS}

Morphological studies. All the powdery mildew fungi obtained from North America, Europe, and Japan produced conidia singly (Fig. 1), and their morphological features corresponded to those of $O$. neolycopersici. They were clearly different from the three Australian specimens of $O$. lycopersici included in this study, which produced conidia in chains (Fig. 2). The morphological differences between $O$. neolycopersici and $O$. lycopersici have been discussed previously (35).

Phylogenetic studies. A total of 10 ITS sequences of $O$. neolycopersici were aligned with sequences from species of Erysiphe sections Erysiphe and $\mathrm{Mi}$ crosphaera obtained from DNA databases. The alignment data matrix consisted of 59 taxa and 614 characters, of which 51 sites were removed because of ambiguous alignment. Of the 563 remaining characters, 181 sites were variable and 123 sites were phylogenetically informative for parsimony analysis. Two isolates of Erysiphe glycines were used as outgroup taxa based on Takamatsu et al. (61). Using Modeltest (51), under the Akaike's (4) information criterion, we concluded that a submodel of the GTR model (53), with unequal base frequencies, a gammadistributed rate heterogeneity model (four rate categories, $\mathrm{G}=0.8657$ ) (71), and an estimated proportion of invariant sites (0.4668) was the most appropriate model

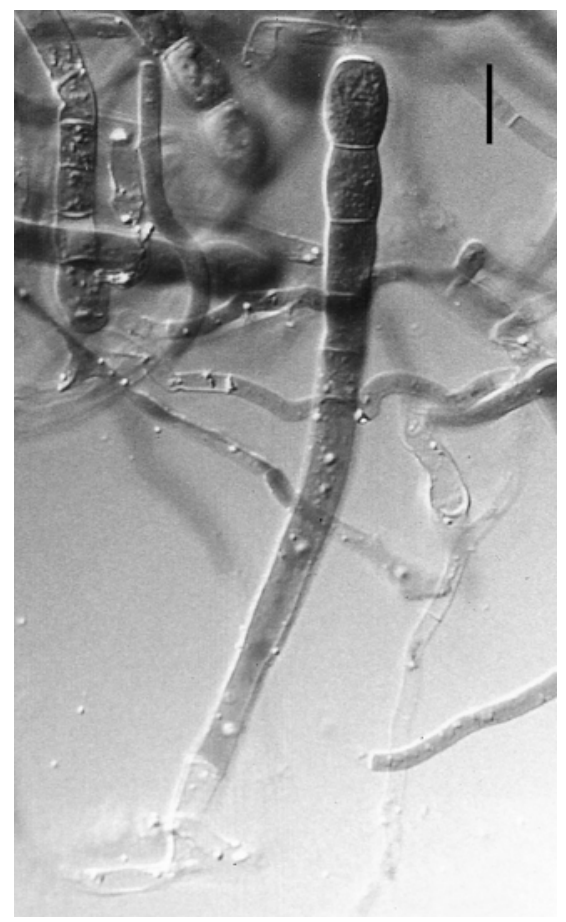

Fig. 2. A conidiophore of Oidium lycopersici collected in South Australia in 1980 and rehydrated in lactic acid from a herbarium specimen (DAR 35763). Bar $=20 \mu \mathrm{m}$. 
of evolution for this data set. ML and NJ trees were constructed under the evolution model. MP analysis found 18 equally parsimonious trees of 421 steps $(\mathrm{CI}=0.5677$, $\mathrm{RI}=0.8002, \mathrm{RC}=0.4543)$. Likelihood scores of the 20 tree topologies were obtained under the evolution model using PAUP*. Only minor differences were found in the branching order of the terminal nodes among the 20 trees. We regarded the MP tree having the highest likelihood score $(-\ln \mathrm{L}=3085.39616)$ as the best tree (Fig. 3)

Of the 10 ITS sequences of $O$. neolycopersici isolates, nine were identical, while the sequence from isolate NETH differed by one base in the ITS2 region. $O$. neolycopersici grouped in a single clade with high bootstrap supports (86 to $87 \%$ in MP, ML, and NJ analyses). The $O$. neolycopersici clade further grouped with $E$. macleayae and $E$. aquilegiae to form a clade with $100 \%$ bootstrap support in all three analyses. These results were consistent with those reported by Jones et al. (30) and Kashimoto et al. (32).

\section{DISCUSSION}

This study has provided the first convincing evidence that the non-catenate Oidium anamorphs responsible for the recent tomato powdery mildew epidemics in the United States and Canada are $O$. neolycopersici. This had already been suggested by a morphological examination of some North American tomato powdery mildew pathogens (35), but it had not been confirmed by any other method to date.

The recent tomato powdery mildew epidemics caused by Oidium anamorphs were reported as outbreaks of a previously unknown disease in North America (5$7,31,37,41,49,57,68)$. Before the 1990s, there was only one record of an Oidium anamorph on tomato seedlings (17). This might suggest that $O$. neolycopersici was introduced to the United States and Canada only recently.

The origin of $O$. neolycopersici is unknown, although the center of origin of the host itself, in the Andes, has not been investigated in this respect. Our phylogenetic analysis demonstrated that $O$. neolycopersici is, indeed, a distinct powdery mildew

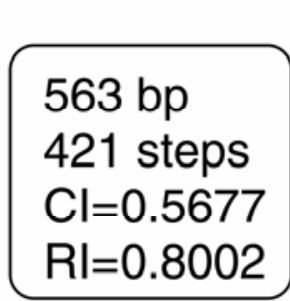

63. Oidium sp. ex Eustoma AB079855

Oidium sp. ex Mirabilis AB079853

Oidium sp. ex Vicia faba AB079854

98 E baeumleri ex Vicia amoena $\mathrm{AB} 015933$

E. baeumleri ex V. cracca AB015919

E. trifolii ex Trifolium AB015913

E. pisi ex Lathyrus AF011306

E. pisi ex Pisum AF073348

72 E. howeana ex Oenothera AF011301

78 Oidium sp. ex Convolvulus AF154328

E. heraclei ex Daucus AB000942

91 E. betae ex Beta AF011290

$77 \quad$ E. polygoni ex Polygonum AF011307

92 E. polygoni ex Rumex AF011308

E. friesii ex Rhamnus A B000939

$100-$ E. glycines var lespedezae ex Lespedeza juncea $\mathrm{AB} 015921$

E. cruciferarum ex Arabidopsis AF031283

E. convolvuli ex Convolvulus AF011298

E. convolvuli ex Convolvulus AF 154327

E. syringae-japonicae ex Syringa AB015920

E. liriodenari ex Liriodendron AF011302

F pserdolonicerae ex Coca AF29854

$82-5$ E. pseudolonicerae ex Cocculus AB015915

E. hypophylla ex Quercus AF298544

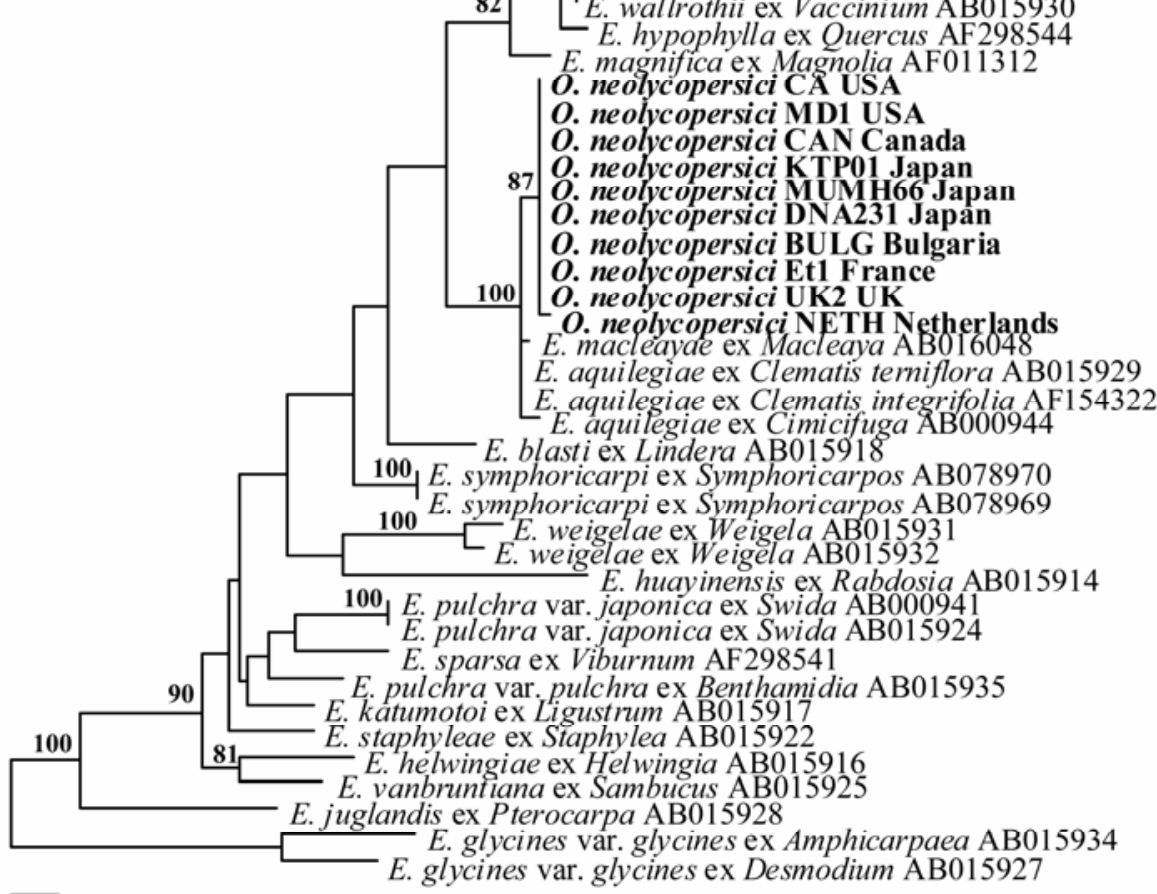

5 substitutions

Fig. 3. A most parsimonious tree based on the nucleotide sequences of the rDNA internal transcribed spacer regions for 59 powdery mildew taxa of Oidium subgenus Pseudoidium, including 10 isolates from tomato (shown in boldface). This tree has the highest likelihood score among a total of 20 trees consisting of 18 equally parsimonious, one neighbor-joining and one maximum likelihood trees. Bootstrap values of 1,000 replications are shown above nodes. DNA database accession numbers for powdery mildew taxa other than $O$. neolycopersici are also shown on the tree. The consistency index (CI) is 0.5677 ; retention index (RI) is 0.8002 ; and rescaled consistency index $(\mathrm{RC})$ is 0.4543 . 
species, and it is neither identical nor closely related to any known polyphagous species of the Erysiphaceae (Fig. 3). European reports, similar to the North American ones, suggest that it has appeared on tomato only recently $(29,44,47,67)$. However, there are records in the older phytopathological and mycological literature of Oidium anamorphs infecting tomato in Europe $(8,22,28,55)$, Sri Lanka (50), Peru (1), and Argentina (21), sometimes causing serious epidemics long before the 1990s (21). Unfortunately, to our knowledge, herbarium specimens were not preserved in any of these cases, so the causal agents of the infections reported in these papers cannot be determined. There are a number of herbarium specimens available from Asia, and collected between 1947 and 1987, which were studied by Kiss et al. (35) who concluded that they were all $O$. neolycopersici based on their morphological features. So, powdery mildew infections of tomato caused by non-catenate Oidium anamorphs, presumably by $O$. neolycopersici, were recorded, at least in Asia, long before the 1990s.

Although the variability reported in the pathogenicity of some $O$. neolycopersici isolates (39) suggests a considerable genetic diversity, a preliminary report of an amplified fragment length polymorphism (AFLP) analysis revealed only minor genetic differences among five isolates collected from tomato in three different European countries (26). This result, together with the ITS sequence data, and the apparent lack of sexual recombination, suggests that there is little genetic variability in $O$. neolycopersici. Further studies are needed for a more comprehensive genetic characterization of this novel pathogen.

\section{ACKNOWLEDGMENTS}

The authors are grateful to the following colleagues for their help in obtaining fungal materials: Adrien Bolay, Raymond Cerkauskas, Roger T. A. Cook, R. Michael Davis, David M. Gadoury, CaiCheng Huang, David Kalb, Margaret T. McGrath, Philippe C. Nicot, Y. Sato, Nina Shishkoff, Victoria L. Smith, and Amy Y. Rossman. The study was partly supported by a grant (OTKA 32931) of the Hungarian Scientific Research Fund and by a Fulbright fellowship and a Janos Bolyai fellowship awarded to LK.

\section{LITERATURE CITED}

1. Abbott, E. V. 1931. Further notes on plant diseases in Peru. Phytopathology 21:10611071.

2. Abiko, K. 1978. Influence of temperature and humidity on development of tomato powdery mildew. Proc. Kansai Plant Prot. Soc. 20:4952.

3. Adam, L., Ellwood, S., Wilson, I., Saenz, G., Xiao, S., Oliver, R. P., Turner, J. G., and Somerville, S. 1999. Comparison of Erysiphe cichoracearum and E. cruciferarum and a survey of 360 Arabidopsis thaliana accessions for resistance to these two powdery mildew pathogens. Mol. Plant-Microbe Interact. 12:1031-1043.

4. Akaike, H. 1974. A new look at the statistical model identification. IEEE Trans. Autom. Control 19:716-723.
5. Arredondo, C. R., Davis, R. M., Rizzo, D. M., and Stahmer, R. 1996. First report of powdery mildew of tomato in California caused by an Oidium sp. Plant Dis. 80:1303.

6. Bains, P. S., Bennypaul, H., and Mirza, M. 1999. First report of powdery mildew of greenhouse-grown tomatoes in Alberta, Canada. Plant Dis. 83:488.

7. Bélanger, R. R., and Jarvis, W. R. 1994. Occurrence of powdery mildew (Erysiphe sp.) on greenhouse tomatoes in Canada. Plant Dis. 78:640.

8. Blumer, S. 1967. Echte Mehltaupilze (Erysiphaceae). G. Fisher Verlag, Jena.

9. Bolay, A. 1998. Les oidiums de la tomate et de l'aubergine en Suisse. Rev. Suisse Vitic. Arboric. Hortic. 30:373-378.

10. Braun, U. 1987. A monograph of the Erysiphales (powdery mildews). Beih. Nova Hedwigia 89:1-700.

11. Braun, U., Cook, R. T. A., Inman, A. J., and Shin, H.-D. 2002. The taxonomy of the powdery mildew fungi. Pages 13-54 in: The Powdery Mildews. A Comprehensive Treatise. R. R. Bélanger, W. R. Bushnell, A. J. Dik, and T. L. W. Carver, eds. American Phytopathological Society, St. Paul, MN

12. Burgerjon, A., Nicot, P. C., Bertrand, F., and Blancard, D. 1990. Early powdery mildew of greenhouse-grown tomatoes in France. (Abstr.) Phytopathology 80:1063.

13. Cook, R. T. A., Inman, A. J., and Billings, C. 1997. Identification and classification of powdery mildew anamorphs using light and scanning electron microscopy and host range data. Mycol. Res. 101:975-1002.

14. Corbaz, R. 1990. L'oidium de la tomate, une maladie nouvelle en Suisse. Rev. Suisse Vitic. Arboric. Hortic. 22:159-161.

15. Cunnington, J. H., Takamatsu, S., Lawrie, A. C., and Pascoe, I. G. 2003. Molecular identification of anamorphic powdery mildews (Erysiphales). Australas. Plant Pathol. 32:421-428.

16. Epinat, C., Pitrat, M., and Bertrand, F. 1993. Genetic analysis of resistance of 5 melon lines to powdery mildews. Euphytica 65:135-144.

17. Farr, D. F., Bills, G. F., Chamuris, G. P., and Rossman, A. Y. 1989. Fungi on Plants and Plant Products in the United States. American Phytopathological Society, St. Paul, MN.

18. Felsenstein, J. 1985. Confidence limits on phylogenies: An approach using the bootstrap. Evolution 39:783-791.

19. Fletcher, J. T., Smewin, B. J., and Cook, R. T. A. 1988. Tomato powdery mildew. Plant Pathol. 37:594-598

20. Gabler, J., Gerlach, W., and Braun, U. 1990. Epidemisches Auftreten eines Mehltaus an Tomaten in der DDR. Nachrichtenbl. Dtsch. Pflanzenschutzdienst (Braunschweig) 42:9495.

21. Godoy, E. F. 1939. El oidium del tomate. Rev. Argentina Agron. 6:49-52.

22. Hammarlund, C. 1945. Beitrage zur Revision einiger imperfekter Mehltau-Arten. Erysiphe polyphaga nov. sp. Bot. Notiser 1945:101-108.

23. Hirata, T., Cunnington, J. H., Paksiri, U., Limkaisang, S., Shishkoff, N., Grigaliunaite, B., Sato, Y., and Takamatsu, S. 2000. Evolutionary analysis of subsection Magnicellulatae of Podosphaera section Sphaerotheca (Erysiphales) based on the rDNA internal transcribed spacer sequences with special reference to host plants. Can. J. Bot. 78:1521-1530

24. Hirata, T., and Takamatsu, S. 1996. Nucleotide sequence diversity of rDNA internal transcribed spacers extracted from conidia and cleistothecia of several powdery mildew fungi. Mycoscience 37:283-288.

25. Huang, C.-C., Biesheuvel, J., Lindhout, P., and Niks, R. E. 2000. Host range of Oidium lycopersici occurring in the Netherlands. Eur. J. Plant Pathol. 106:465-473.

26. Huang, C.-C., Lindhout, P., and Niks, R. E.
1998. Genetic differences in powdery mildews prevailing recently on tomato. Abstr. Int Congr. Plant Pathol. '98, Edinburgh, 2.2.18.

27. Inman, A. J., Cook, R. T. A., and Beales, P. A. 2000. A contribution to the identity of rhododendron powdery mildew in Europe. J. Phytopathol. 148:17-27.

28. Jaczewski, A. A. 1927. Guide Book to the Identification of Fungi. Leningrad. (In Russian)

29. Jones, H., Whipps, J. M., and Gurr, S. J. 2001. The tomato powdery mildew fungus Oidium neolycopersici. Mol. Plant Pathol. 2:303-309.

30. Jones, H. E., Whipps, J. M., Thomas, B. J., Carver, T. L. W., and Gurr, S. J. 2000. Initial events in the colonisation of tomatoes by Oidium lycopersici, a distinct powdery mildew fungus of Lycopersicon species. Can. J. Bot. 78:1361-1366.

31. Karasevicz, D. M., and Zitter, T. A. 1996. Powdery mildew occurrence on greenhouse tomato plants in New York. Plant Dis. 80:709.

32. Kashimoto, K., Matsuda, Y., Matsutani, K., Sameshima, T., Kakutani, K., Nonomura, T. Okada, K., Kusakari, S., Nakata, K., Takamatsu, S., and Toyoda, H. 2003. Morphological and molecular characterization for a Japanese isolate of tomato powdery mildew Oidium neolycopersici and its host range. J. Gen. Plant Pathol. 69:176-185.

33. Kashimoto, K., Sameshima, T., Matsuda, Y., Nonomura, T., Oichi, W., Kakutani, K., Nakata, K., Kusakari, S., and Toyoda, H. 2003. Infectivity of a Japanese isolate of Oidium neolycopersici KTP-01 to a European tomato cultivar resistant to $O$. lycopersici. J. Gen. Plant Pathol. 69:406-408.

34. Kiss, L. 1996. Occurrence of a new powdery mildew fungus (Erysiphe sp.) on tomatoes in Hungary. Plant Dis. 80:224.

35. Kiss, L., Cook, R. T. A., Saenz, G. S., Cunnington, J. H., Pascoe, I., Bardin, M., Nicot, P. C., Takamatsu, S., Sato, Y., and Rossman, A. Y. 2001. Identification of two powdery mildew fungi, Oidium neolycopersici sp. nov. and $O$. lycopersici, infecting tomato in different parts of the world. Mycol. Res. 105:684-697.

36. Kusaba, M., and Tsuge, T. 1995. Phylogeny of Alternaria fungi known to produce hostspecific toxins on the basis of variation in in ternal transcribed spacers of ribosomal DNA. Curr. Genet. 28:491-498.

37. LaMondia, J. A., Smith, V. L., and Douglas, S M. 1999. Host range of Oidium lycopersicum on selected Solanaceous species in Connecticut. Plant Dis. 83:341-344.

38. Lebeda, A., and Mieslerova, B. 1999. Identification, occurrence and host range of tomato powdery mildew (Oidium lycopersici) in the Czech Republic. Acta Phytopathol. Entomol. Hung. 34:13-25.

39. Lebeda, A., and Mieslerova, B. 2002. Variability in pathogenicity of Oidium neolycopersici on Lycopersicon species. Z. Pflanzenkrankh. Pflanzenschutz 109:129-141.

40. Lindhout, P., Pet, G., and Van der Beek, H. 1994. Screening wild Lycopersicon species for resistance to powdery mildew (Oidium lycopersicum). Euphytica 72:43-49.

41. Marois, J. J., Momol, M. T., Kimbrough, J. W. Hochmuth, R. C., and Dankers, W. 2001. First report of powdery mildew on greenhouse tomatoes caused by Oidium neolycopersici in Florida. Plant Dis. 85:1292.

42. Matsuda, S., and Takamatsu, S. 2003. Evolution of host-parasite relationships of Golovinomyces (Ascomycete: Erysiphaceae) inferred from nuclear rDNA sequences. Mol. Phylogenet. Evol. 27:314-327.

43. Matsuda, Y., Kashimoto, K., Takikawa, Y., Aikami, R., Nonomura, T., and Toyoda, H 2001. Occurrence of new powdery mildew on greenhouse tomato cultivars. J. Gen. Plant Pathol. 67:294-298. 
44. Mieslerova, B., and Lebeda, A. 1999. Taxonomy, distribution and biology of the tomato powdery mildew (Oidium lycopersici). Z. Pflanzenkrankh. Pflanzenschutz 106:140-157.

45. Mori, Y., Sato, Y., and Takamatsu, S. 2000. Evolutionary analysis of the powdery mildew fungi using nucleotide sequences of the nuclear ribosomal DNA. Mycologia 92:74-93.

46. Neshev, G. 1993. Powdery mildew (Oidium sp.) on tomatoes in Bulgaria. Phytoparasitica 21:339-343.

47. Noordeloos, M. E., and Loerakker, W. M. 1989. Studies in plant pathogenic fungi - II. On some powdery mildews (Erysiphales) recently recorded from the Netherlands. Persoonia 14:51-60.

48. Olalla, L., and Torés, J. A. 1998. First report of powdery mildew of tomato caused by an Erysiphe sp. in Spain. Plant Dis. 82:592.

49. Pernezny, K., and Sonoda, R. M. 1998. Powdery mildew of field-grown tomato in Florida. Plant Dis. 82:262.

50. Petch, T. 1922. Additions to Ceylon fungi. II. Ann. Royal Bot. Gardens, Peradeniya 7:279322.

51. Posada, D. and Coandall, K. A. 1998. Modeltest: Testing the model of DNA substitution. Bioinformatics 14:817-818.

52. Price, T. V. 1981. Powdery mildew of tomato in Australia. Australas. Plant Pathol. 10:38-40.

53. Rodriguez, F., Oliver, J. F., Martin, A., and Medina, J. R. 1990. The general stochastic model of nucleotide substitutions. J. Theor. Biol. 142:485-501.

54. Saenz, G. S., and Taylor, J. W. 1999. Phylogeny of the Erysiphales (powdery mildews) inferred from internal transcribed spacer ribosomal DNA sequences. Can. J. Bot. 77:150168 .
55. Salmon, E. S. 1900. A monograph of the Erysiphaceae. Mem. Torrey Bot. Club 9:1-292.

56. Shin, H. D., and La, Y.-J. 1993. Morphology of edge lines of chained immature conidia on conidiophores in powdery mildew fungi and their taxonomic significance. Mycotaxon 46:445451.

57. Smith, V. L., Douglas, S. M., and LaMondia, J. A. 1997. First report of powdery mildew of tomato caused by an Erysiphe sp. in Connecticut. Plant Dis. 81:229.

58. Swofford, D. L. 2001. PAUP*: Phylogenetic Analysis Using Parsimony (*and other methods). Version 4.0b8. Sinauer, Sunderland, MA.

59. Takamatsu, S., Hirata, T., and Sato, Y. 1998. Phylogenetic analysis and predicted secondary structures of the rDNA internal transcribed spacers of the powdery mildew fungi (Erysiphaceae). Mycoscience 39:441-453.

60. Takamatsu, S., Hirata, T., and Sato, Y. 2000. A parasitic transition from trees to herbs occurred at least twice in tribe Cystotheceae (Erysiphaceae): Evidence from nuclear ribosomal DNA. Mycol. Res. 104:1295-1303.

61. Takamatsu, S., Hirata, T., Sato, Y., and Nomura, Y. 1999. Phylogenetic relationships of Microsphaera and Erysiphe section Erysiphe (powdery mildews) inferred from the rDNA ITS sequences. Mycoscience 40:259-268.

62. Takamatsu, S., Shin, H.-D., Paksiri, U., Limkaisang, S., Taguchi, Y., Thi Binh, N., and Sato, Y. 2002. Two Erysiphe species associated with recent outbreak of soybean powdery mildew: Results of molecular phylogenetic analysis based on nuclear rDNA sequences. Mycoscience 43:333-341.

63. Thompson, J. D., Gibson, T. J., Plewniak, F., Jeanmougin, F., and Higgins, D. G. 1997. The ClustalX windows interface: Flexible strate- gies for multiple sequence alignment aided by quality analysis tools. Nucleic Acids Res. 24:4876-4882.

64. Vakalounakis, D. J., and Papadakis, A. 1992 Occurrence of a new powdery mildew of greenhouse tomato in Greece, caused by Erysiphe sp. Plant Pathol. 41:372-373.

65. Vogel, J., and Somerville, S. 2002. Powdery mildew of Arabidopsis: A model system for host-parasite interactions. Pages 161-168 in: The Powdery Mildews. A Comprehensive Treatise. R. R. Bélanger, W. R. Bushnell, A. J. Dik, and T. L. W. Carver, eds. American Phytopathological Society, St. Paul, MN.

66. Walsh, P. S., Metzger, D. A., and Higuchi, R. 1991. Chelex 100 as a medium for simple extraction of DNA for PCR-based typing from forensic material. BioTechniques 10:506-513.

67. Whipps, J. M., Budge, S. P., and Fenlon, J. S 1998. Characteristics and host range of tomato powdery mildew. Plant Pathol. 47:36-48.

68. White, J. F., Jr., Johnston, S. A., Wang, C.-L., and Chin, C.-K. 1997. First report of powdery mildew in greenhouse-grown tomatoes in New Jersey. Plant Dis. 81:227.

69. White, T. J., Bruns, T., Lee, S., and Taylor, J. 1990. Amplification and direct sequencing of fungal ribosomal RNA genes for phylogenetics. Pages 315-322 in: PCR Protocols: A Guide to Methods and Applications. D. H. Gelfand, J. J. Sninsky, and T. J. White, eds. Academic Press, New York.

70. Wicks, T. J., and Clare, B. G. 1981. Powdery mildew on tomatoes. Australas. Plant Pathol. 10:36-37.

71. Yang, Z. 1994. Maximum likelihood phylogenetic estimation from DNA sequences with variable rates over sites: Approximate methods. J. Mol. Evol. 39:306-314. 